Forest Ecology and

Management

\title{
A comparison of wetland tree growth response to hydrologic regime in Louisiana and South Carolina
}

\author{
B.D. Keeland ${ }^{\mu,}$, W.H. Conner ${ }^{b}$, R.R. Sharitz ${ }^{c}$ \\ - National Biological Survey, Southern Science Center, 700 Cajundome Btud, Lafayetie, LA 70506, USA \\ Baruch Forest Science Institute, Box 596, Georgetown, SC 29442, USA \\ - Savannah River Ecology Laboratory. Drawer E. Aiken, SC 29802, USA
}

\begin{abstract}
Numerous investigations have examined the growth of wetland tree species under a variety of hydrologic conditions. Most studies have compared flooded versus non-flooded conditions in greenhouses or in one to a few field sites near each other or within the same region. Comparisons of wetland tree growth among widely separated areas of the country are rare. This study compared the diametet growth of Nyssa sylvatica var. biflora, Nyssa aquatica, and Taxodium distichum trees from Louisiana (Gulf Coastal Plain) and South Carolina (Atlantic Coastal Plain). In both regions, individual trees were distributed along a gradient of hydrologic regimes from infrequent to permanent flooding. Nyssa syluatica var. biflora was restricted to periodically flooded sites in both regions. Within these sites, this species showed little response to differences in mean water depth. In contrast, significant differences among hydrologic regimes were detected for $N$. aquatica in both regions. In Louisiana, patterns of growth response did not correlate with the gradient of hydrologic regimes, but in South Carolina maximum growth was inversely related to mean water levels during the growing season. Maximum growth of $T$. distichum trees was observed at sites with shallow, permanent flooding in both regions.
\end{abstract}

Keywords: Flooding: Hydrologic regime; Louisiana; South Carolina; Tree growth; USA

\section{Introduction}

The attention focused on forested wetlands in recent years has resulted in a better understanding of the functions and values of these important ecosystems (Mitsch et al., 1979; Brown, 1981; Wharton et al., 1982; Mitsch and Gosselink, 1993). One result of this work has been the demonstration that species distributions in forested wetlands are related to flood frequency and duration (Bedinger, 1971; Leitman et al., 1982; Paratley and Fahey, 1986; Hughes, 1990). This implies optimum positions for each species

\footnotetext{
Corresponding author.
}

along a hydrologic gradient in a manner similar to that described for elevation gradients in the Great Smoky mountains by Whittaker (1956) and agrees with the individualistic concept of Gleason (1926).

Phipps (1979) and Phipps and Applegate (1983) proposed optimum positions for wetland forest species along a hydrologic gradient. Near the midpoint of its hydrologic zone of tolerance, each species should occur more frequently and grow faster. Toward the edges of the zone of tolerance, where flooding is more or less frequent and of shorter or longer duration, the abundance and growth of a species should decrease. Phipps (1979) and Pearlstine (1985) used this assumption in their forest simu- 
lation models SWAMP and FORFLO to create reduced values for individual tree growth in areas subjected to suboptimal hydrologic conditions.

Several investigators have examined the effects of flooding on the productivity of bottomland hardwood and swamp ecosystems in the southeastern United States. Most of these studies concentrated on the structure and function of individual wetlands (Langdon et al., 1978; Schlesinger, 1978; Mitsch et al., 1979; Weller, 1989) or compared wetlands in the same local area. For example, researchers have compared sites in Florida (Monk and Brown, 1965: Mitsch and Ewel, 1979; Brown, 1981), Louisiana (Conner and Day, 1976; Conner et al., 1981; White, 1983: Dicke and Toliver, 1990) and Virginia (Day, 1985; Megonigal and Day, 1988). Each of these studies provided valuable information on forested wetland community differences. Most, however, have considered a limited range of hydrologic conditions, and comparisons among widely separated areas are rare.

We compared the effect of hydrologic regime on wetland-tree growth between two regions of the southeastern coastal plain. Study areas located in Louisiana (Gulf Coastal Plain) and in South Carolina (South Atlantic Coastal Plain) were separated by a distance of more than $1000 \mathrm{~km}$. Three tree species that are common canopy dominants in deepwater swamps throughout the southeastern United States were chosen for study: Nyssa syluatica var. biflora (Walter) Sargent (swamp tupelo), N. aquatica L. (water tupelo) and Taxodium distichum (L.) Rich. (baldcypress). In this paper Nyssa syluatica var. biflora is referred to as Nyssa syluatica.

Our objectives were to compare the amount, duration and pattern (timing within the growth phase) of diameter growth of individual trees of each species by region (Atlantic Coastal Plain vs. Gulf Coastal Plain) and within each region by position along the hydrologic gradient.

\section{Materials and methods}

Study sites in Louisiana and South Carolina were chosen based on availability of tree growth data and the extensive amount of prior research at these sites. Data collection in Louisiana was conducted in 1987 while South Carolina data was collected in 1989 and 1990. Although data from the two regions were collected during different years, the comparisons are considered valid because discussions are presented in terms of the current and previous year weather patterns in each case. In addition, due to the distance separating these study areas $(>1000 \mathrm{~km})$ local weather conditions in one area do not necessarily reflect contemporaneous conditions in the other area.

\section{I. Study areas in Louisiana}

The three study areas in the Gulf Coastal Plain of southeastern Louisiana were the Verret basin, Barataria basin and the Pearl river swamp (Fig. 1). In each area, three study sites were selected to represent the local hydrologic gradient. Collectively, the nine study sites represented a gradient of hydrologic regimes based on mean growing season water levels. Water levels ranged from below the soil surface and infrequent surface flooding at the highest Pearl river site, through soil saturation and very shallow flooding at the Verret basin sites, to permanent shallow flooding at the Barataria basin sites. Due to the similarity of hydrologic regimes and a low number of trees, the two least flooded sites in the Pearl river area were combined. Similarly, the two most flooded sites in the Barataria basin area were combined, resulting in a total of seven study sites in Louisiana (Table 1).

\subsubsection{Pearl river swamp}

The Pearl river swamp is in the floodplain between the West Pearl and Pearl rivers in St. Tam. many Parish. This relatively undisturbed backwater area is inundated by overbank flooding of the Pearl river during high water periods. Soils range from fine, silty, mixed, acid, thermic Aeric Fluvaquents of the Arkabutla series on the least flooded site to fine-silty, mixed, acid, thermic Typic Fluvaquents of the Rosebloom series on the frequently flooded site. The two Pearl river study sites were referred to as LA (the least flooded, pooled site) and LC.

\subsubsection{Verret basin}

The Verret basin swamp is located between Bayou Lafourche and the Atchafalaya floodway in Assumption Parish. Water levels are influenced primarily by 


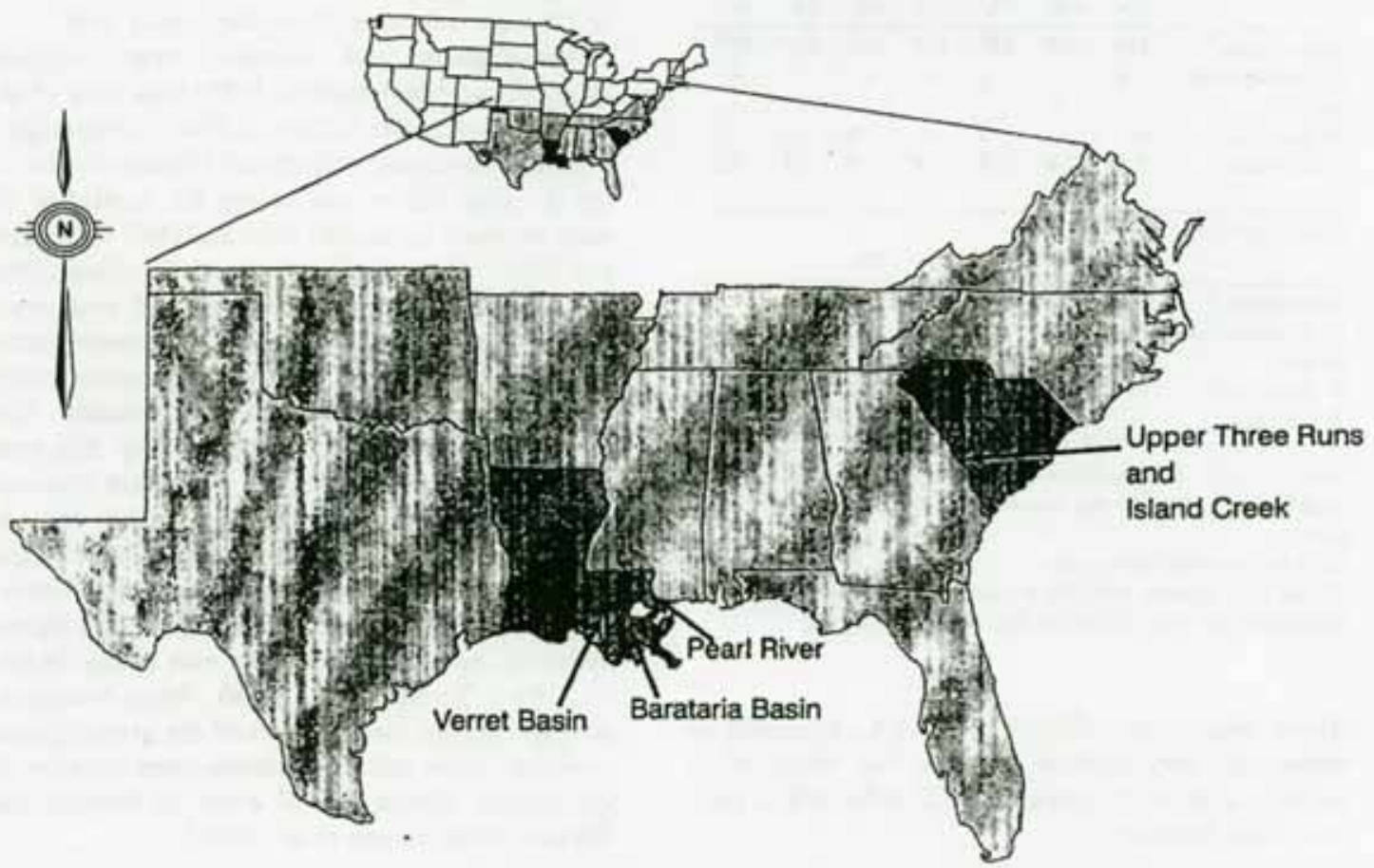

Fig. 1. Locations of the study siles within the southeastern United States.

subsidence and secondarily by rainfall, backwater flooding and upland runoff (Conner and Day, 1988). Soils, thermic Typic Fluvaquents of the Fausse series, include clayey and silty sediments deposited from flooding by the Mississippi and Atchafalaya rivers. The three Verret basin study sites were referred to as LB, LD and LE, listed in order of increased mean water levels.

\subsubsection{Barataria basin}

The Barataria basin swamp occurs between the Mississippi river and Bayou Lafourche in Terre. bonne Parish. Water levels are determined primarily by local rainfall. Soils, thermic Vertic Haplaquepts of the Sharkey series, are poorly drained and subject to frequent flooding. They include clay and silty clay sediments deposited by floods of the Mississippi river and are overlain by organic matter varying in thickness and degree of decomposition. The two Barataria basin study sites were referred to as LF and LG (pooled site) and are the Louisiana areas with the deepest mean growing season water levels.

\subsection{Study areas in South Carolina}

Five study sites in South Carolina represented a gradient of hydrologic regimes from infrequent shallow flooding to deep, permanent flooding. The sites were within the Savannah river floodplain in the upper South Atlantic Coastal Plain of South Carolina, in Aiken County (Fig. 1). Soils at all sites were acidic, poorly drained, and slowly permeable, classified as Typic Fluvaquents of the Chastain series (Rogers, 1990).

\subsection{Upper Three Runs creek}

Three sites were located along Upper Three Runs creek, a tributary of the Savannah river. Flood frequency, depth and duration were related to site elevation, rainfall in the Upper Three Runs creek watershed, and a backwater effect caused by high water in the Savannah river. Soils at the two highest sites (SA and SB) generally remained between field capacity and saturation between floods, whereas the lowest site was almost always saturated (Keeland, 1994). 
Table 1

Total stem density and number of trees of each species per study site in Louisiana and South Carolina

\begin{tabular}{|c|c|c|c|c|c|c|c|}
\hline Louisiana & $\mathrm{LA}^{*}$ & LB & LC & LD & LE & LF & LG \\
\hline Stem density & 540 & 450 & 550 & 575 & 530 & 930 & 880 \\
\hline $\begin{array}{l}\text { N. syluarice var. } \\
\text { biflere }\end{array}$ & 2 & - & 8 & - & - & - & - \\
\hline N. aquatica & - & - & 5 & - & 4 & 3 & 2 \\
\hline T. disrichurn & - & 4 & 8 & 5 & 9 & 13 & 10 \\
\hline \multicolumn{8}{|l|}{ South Carolina } \\
\hline & $S A^{*}$ & SB & SC & SD & SE & & \\
\hline Stern deasity ${ }^{b}$ & 540 & 630 & 600 & 745 & 780 & & \\
\hline $\begin{array}{l}\text { N. syluatica var. } \\
\text { biflora }\end{array}$ & 14 & 23 & 41 & - & - & & \\
\hline N. acquatica & - & - & 90 & 42 & 22 & & \\
\hline T. distichum & - & 15 & 44 & 27 & 30 & & \\
\hline
\end{tabular}

Study sites in each state are listed along a hydrologic gradient, with higher mean growing season water levels to the right in the table.

-See text for site descriptions.

Total stem density includes all species present in each plot, in addition to the three species included in this analysis.

These sites were referred to as: SA, subjected to infrequent, very shallow flooding; SB, subjected to periodic shallow flooding; and SC, subjected to periodic deep flooding.

\subsubsection{Island creek}

Two permanently flooded sites were located on Island creek, a small backwater tributary of Upper Three Runs creek. Water level variations caused by rainfall in the small Island creek watershed were much less than variations on Upper Three Runs creek. Occasional deep flooding was caused by high water in the Savannah river. These sites were referred to as: SD, subjected to essentially permanent, shallow flooding, and SE, subjected to permanent, deep flooding.

\subsection{Environmental measurements}

In Louisiana, above ground and/or below ground water levels were measured at 20 to 30 points per study site each week during 1987 and means were calculated. Growing season means and variances also were calculated for each study site. Water levels were recorded hourly with data loggers at one well per study site in South Carolina from mid-March 1989 through December 1990 (Keeland, 1994). Daily and growing season means and variances in water levels were calculated from the hourly data.

Precipitation and potential evapotranspiration (Thornthwaite and Mather, 1955) data were obtained from the Louisiana Office of State Climatology and from the Southeastern Regional Climate Center. Data for the year before and during the year(s) of study were summed by month (1986 and 1987 for Louisiana and 1988, 1989 and 1990 for South Carolina). Months when precipitation exceeded potential evapotranspiration were considered periods of moisture excesses. whereas moisture deficits occurred when potential evapotranspiration exceeded precipitation. Conditions of moisture deficit calculated by this method represent periods of drought, which are detrimental to tree growth (Muller, 1975). Although most trees in this study were in saturated soils or standing water, high evapotranspiration stress can limit water uptake as a result of stomatal closure and increased hydraulic resistance across the root cortex (Kozlow. ski, 1984: Tumer et al., 1984). When temperatures are high during the later part of the growing season, available water and transpiration rates become limiting factors (Fritts, 1956) even in flooded plants (Parker, 1950; Lange et al., 1971).

\subsection{Tree growth measurements}

In Louisiana, aluminum dendrometer bands were installed on all trees $>10 \mathrm{~cm}$ diameter at breast height (dbh) in the fall of 1986 (Table 1). Weekly measurements of cumulative change in circumference were recorded from 31 March through 10 September 1987. Stainless steel dendrometer bands were installed on South Carolina trees $>10 \mathrm{~cm}$ dbh during the late summer of 1988 (Table 1). The cumulative change in circumference of each tree was measured weekly from 22 March through 8 Novem. ber 1989 and from 2 April through 20 November 1990 (Keeland, 1994).

\subsection{Statistical analysis}

Differences in seasonal growth patterns between regions and among hydrologic regimes were analyzed by comparing parameter estimates from non- 
linear regression models of the cumulative diameter growth curve of each tree. The procedure was based on a reparameterized Richards growth model that allowed independent estimation of the three major characteristics of growth curves: (1) maximum size (diameter growth), (2) growth-phase length and (3) growth-curve shape (White and Ratti, 1977; Brisbin et al., 1987). The three parameters of the Richards function were estimated with nonlinear least-squares curve-fitting procedures (PROC NLIN, SAS Institute Inc., 1988). The differential equation used in the model had the form:

$\frac{\mathrm{d} W}{\mathrm{~d} t}=\frac{2(M+1)}{T(1-M)}\left(A^{1-M} W_{i}^{M}-W_{i}\right)+e_{i}$

where $M$ was the Richards growth-curve shape parameter, $T$ the overall growth-phase length, $A$ the asymptotic maximum size, $W_{i}$ the tree diameter at time $t_{i}$, and $e_{i}$ the stochastic error at time $t_{i}$. To reduce bias in shape-parameter estimation, the mean of each of two successive diameters $\left(W_{i}+W_{i+1}\right) / 2$ was used in place of individual diameter measurements (McCallum and Dixon, 1990).

The growth-curve shape value was included in this study because it expresses the pattern of growth throughout the growth phase (which is not the same as the timing of growth in the growing season). A curve-shape value of $M=0$ represents a curve for which maximum growth rates occur at the beginning of the growth phase (the negative exponential), whereas a curve-shape value of $M=2$ is identical to the logistic sigmoid model (Brisbin et al., 1987). As $M$ increases (termed a decretion in curve shape), the period of maximum growth rates occurs later in the growth phase.

Differences in diameter growth, growth-phase length and curve shape between regions and among hydrologic regimes were tested for significance using a nested analysis of variance (ANOVA with hydrologic regime nested within region). Annual diameter-growth data were log-transformed to stabilize the variance (Day and Quinn, 1989). All analyses were performed using procedure GLM, version 6.03 of the Statistical Analysis Systems (SAS Institute Inc., 1988). Least-squares means were used because of the uneven distribution of trees at each study site, and significance levels for multiple comparisons were Bonferroni adjusted (Snedecor and Cochran, 1980).

\section{Results}

\subsection{Water level measurements}

Water levels in Louisiana were lowest at the periodically flooded Pearl river site LA, where the mean growing season water level in 1987 was $67 \mathrm{~cm}$ below the soil surface (Fig. 2). Surface flooding at this site was rare. Pearl river site LC had a higher mean water level $(-7 \mathrm{~cm})$ and was subjected to shallow flooding during the growing season. Mean water levels at the backwater sites (Verret and Barataria basins) were generally higher and increased from a minimum of $15 \mathrm{~cm}$ below the soil surface at Verret site LB to a high of $28 \mathrm{~cm}$ above the soil surface at Barataria site LG (Fig. 2). Water level variance was much less at the backwater sites in the Verret and Barataria basins than at the periodically flooded Pearl river sites.

Water levels in South Carolina increased along the hydrologic gradient from a low of $20 \mathrm{~cm}$ below the soil surface at the infrequently flooded riverine site (SA) to a high of $89 \mathrm{~cm}$ above the soil surface at the deeply flooded backwater site (SE) in 1989 (Fig.
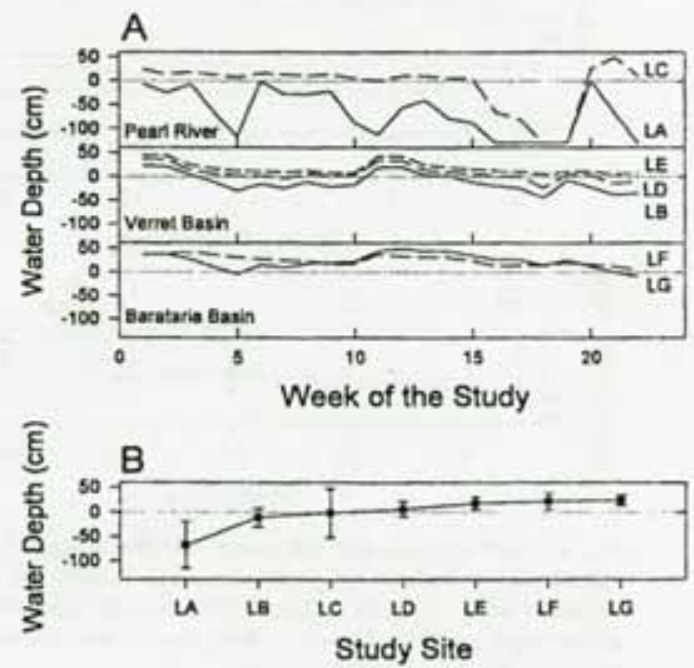

Fig. 2. Water levels in Lovisiana. (A) Water depth for each site during the study period (beginning April 1, 1987). (B) Mean water levels for each study sile. Sites are arranged along a hydrologic gradient of mean growing season water levels. Error bars represent one standard deviation. 
3). Water levels at all sites except SC were lower in 1990 due to low precipitation. Water level variances increased with increasing mean water levels at the periodically flooded riverine sites (SA, SB and SC) but were much lower at the backwater sites (SD and SE).

\subsection{Environmental data}

In Louisiana, temperatures averaged about $20.0^{\circ} \mathrm{C}$ during 1987 , with a minimum of $9.7^{\circ} \mathrm{C}$ in January and a maximum of $28.2^{\circ} \mathrm{C}$ in August. Temperatures fluctuated widely during the winter and early spring. but rose to above $20^{\circ} \mathrm{C}$ in mid-April and remained above that level until late September (Fig. 4). The 1987 growing season (number of days between last spring and first fall frost $\left(0^{\circ} \mathrm{C}\right)$ ) lasted 261 days. In South Carolina, monthly temperatures in 1989 averaged $17.8^{\circ} \mathrm{C}$, with a minimum of $9.9^{\circ} \mathrm{C}$ in January and a maximum of $27.2^{\circ} \mathrm{C}$ in July. Slightly higher
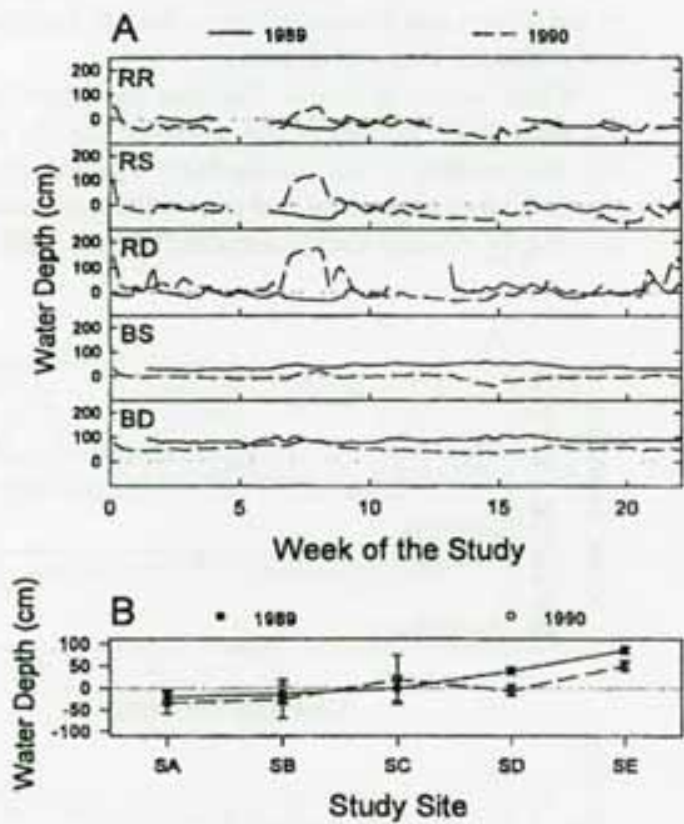

Fig. 3. Water levels in South Carolina. (A) Water depth for each site during the study period (beginaing April 1. 1989 and 1990). (B) Mean water levels for each study site. Sites are arranged along a hydrologic gradient of mean growing season water levels. Error bars represent one standard deviation.
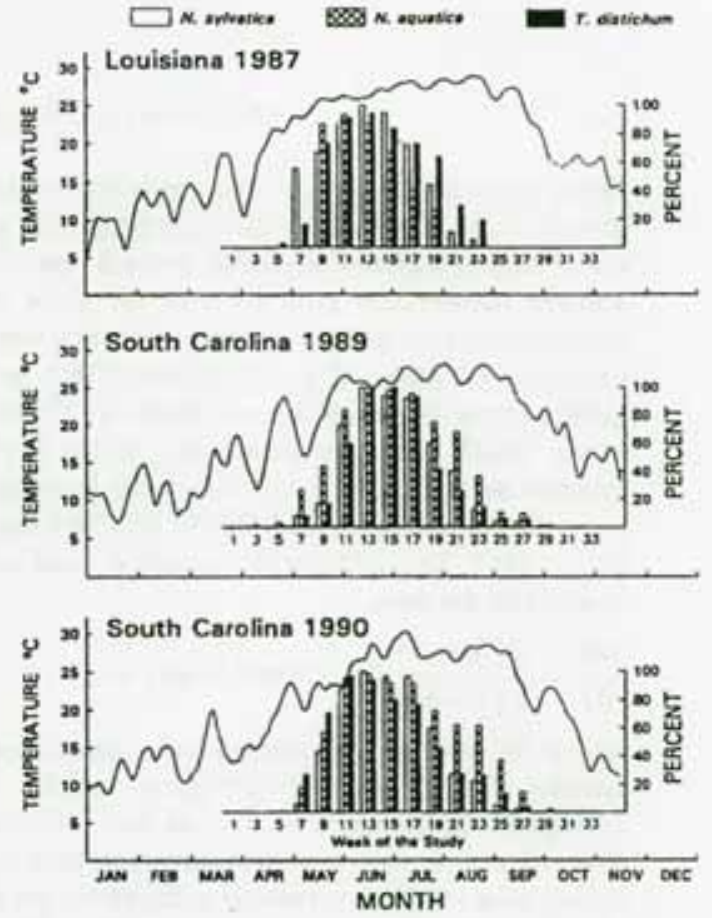

Fig. 4. Air temperature patterns during 1987 in Louisiana and 1989 and 1990 in South Carolina. Bar graphs in each panel indicate the percentage of trees, by species, that were actively growing during each two-woek time period.

temperatures were recorded in 1990, with a mean of $19^{\circ} \mathrm{C}$, a minimum of $10.7^{\circ} \mathrm{C}$ in January and a maximum of $28.3^{\circ} \mathrm{C}$ in July. Spring and summer temperature patterns were more variable than in Louisiana (Fig. 4). Temperatures were not maintained above $20^{\circ} \mathrm{C}$ until early to mid-May in both years. The growing seasons were substantially shorter than in Louisiana, lasting 192 days in 1989 and 199 days in 1990.

Total precipitation in Louisiana ranged from 150 $\mathrm{cm}$ at the Pearl river area to $185 \mathrm{~cm}$ in the Barataria basin in 1987. Evapotranspiration demand exceeded precipitation during both the 1986 and 1987 growing seasons at the Pearl river study sites (Fig. 5). All of the 1986 and nearly all of the 1987 growing seasons were periods of moisture deficit. In the Verret and Barataria basins, the year of data collection (1987) was relatively wet, with moisture excess during 


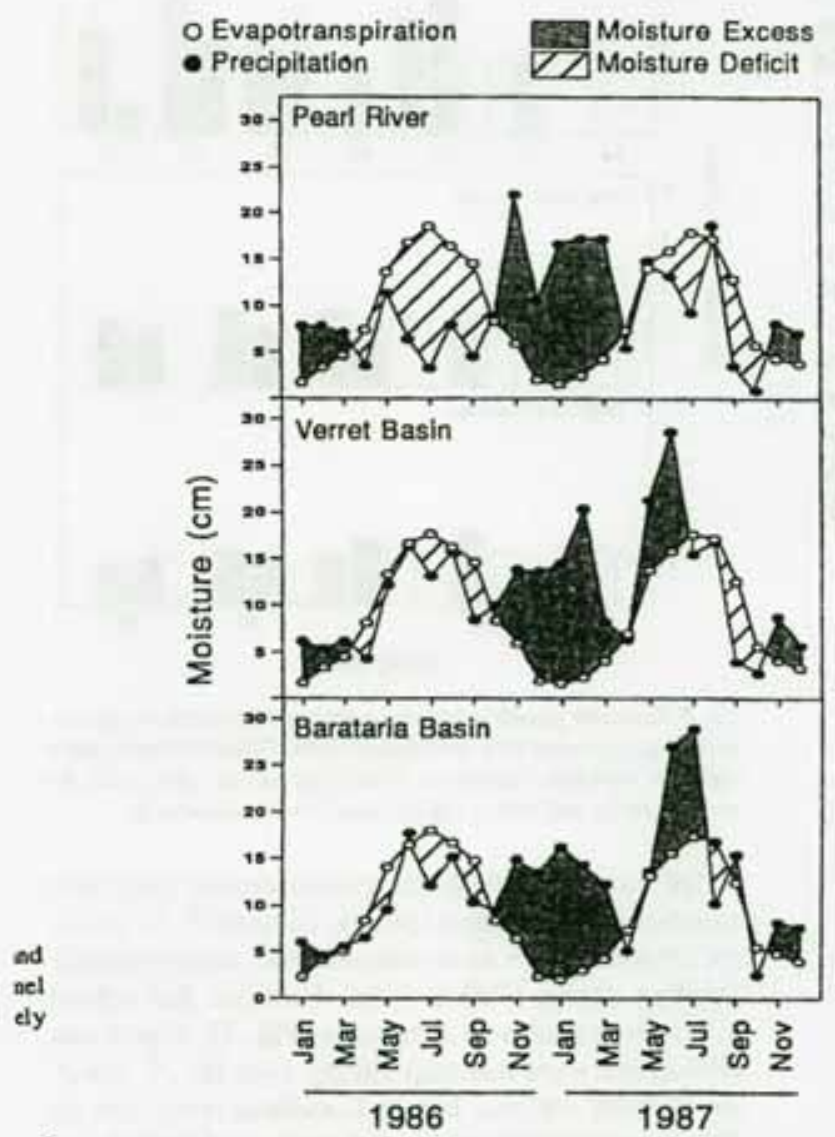

of

xi-

$\mathrm{ra}-$

ina

we

he

in

in

150

uria

led

ing

I of

ons

and

87)

ing
Fig. 5. Weather pattems for the three Louisiana study arras showing monthly lotal precipitation and potential evapotranspira. tion. Moisture excess occurred when precipitation exceeded evapotranspiration.

spring. Precipitation decreased during July to September, resulting in a slight moisture deficit during the later part of the growing season. Conditions during the previous growing season (1986) suggested a moderate climate and an evapotranspiration demand that was only slightly greater than precipitation.

In South Carolina, total precipitation was $133 \mathrm{~cm}$ in 1989 and $116 \mathrm{~cm}$ in 1990 . The first year of data collection (1989) was relatively wet, with precipitation exceeding potential evapotranspiration for the first half of the growing season (Fig. 6). Both the previous year (1988) and the second year of data collection (1990) were characterized by moisture deficits, where evapotranspiration demand exceeded precipitation during the entire growing season.

\subsection{Tree growth response}

\subsubsection{Growth initiation and cessation}

In Louisiana, most individuals of all three species (especially the two Nyssa species) began growing during a very short time period in early May, well after the last major cold period (Fig. 4). Growth cessation occurred over a much longer time period than growth initiation; $N$. aquatica stopped growing first, and $T$. distichum stopped growing last.

Although some trees of all species in South Carolina began to grow during April of 1989. most stems began growing in late-May (Fig. 4). In 1990 , most trees began growing during mid- to late-May. In both years, all three species showed a slow increase in the percentage of trees that were growing. Differences between years in growth initiation dates for $N$. syluatica and $T$. distichum in South Carolina were significant (Keeland, 1994). Growth cessation for all three species showed a decreasing percentage of growing trees that lasted from July until late September during both years. Almost all stems had stopped growing before air temperatures began to decrease substantially.

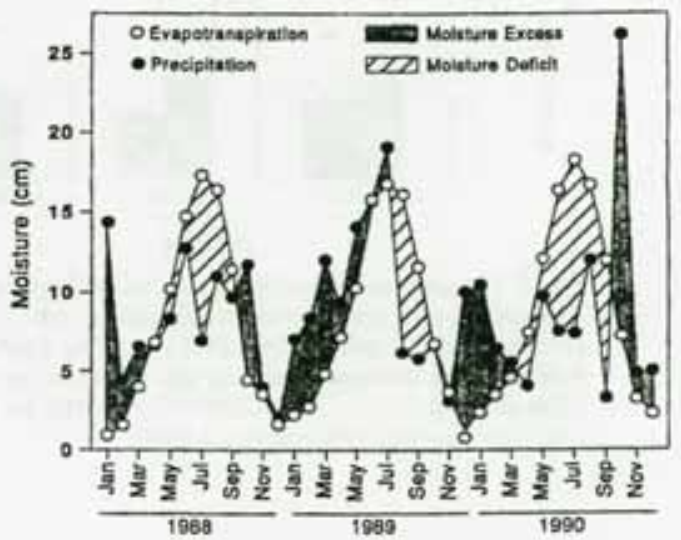

Fig. 6. Weather patterns for the South Carolina study area showing monthly total precipitation and potential evapotranspiration. 


\subsection{Diameter growth}

Although $N$. sylvatica and $N$. aquatica seemed to achieve greater diameter growth in Louisiana than in South Carolina, differences between regions were not significant (Fig. 7). Growth of $T$, distichum in Louisiana was significantly greater than growth of this species during 1990 in South Carolina. Differences in diameter growth between years were significant for all three species in South Carolina (Keeland, 1994). The lack of significant differences in the growth of Nyssa between regions may have been related to the low sample size (Table 1) and wide confidence intervals in Louisiana. Although the absolute difference in $N$. sylvatica growth between Louisiana and South Carolina (in 1990) was greater than the difference in $T$. distichum growth, sample sizes were larger and confidence intervals were narrower for Taxodium.
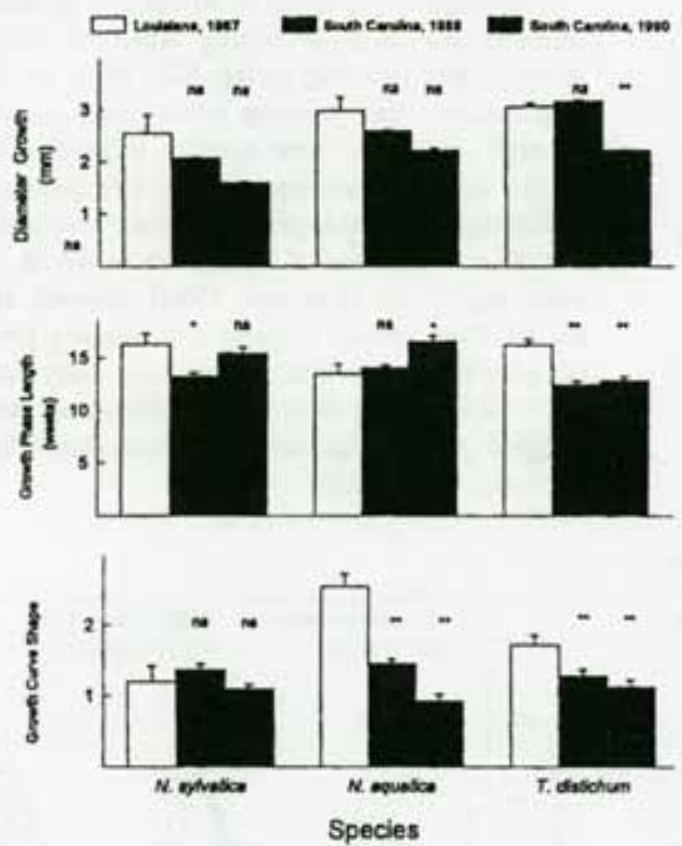

Fig. 7. Comparison of Louisiana and South Carolina data for diameter growth, growth phase length and growth curve shape $(M)$, by species. Symbols above each year of the South Carolina data indicating differences between that value and the Louisiana value are significant at: ${ }^{\cdots}, P<0.001 ;{ }^{*}, P<0.05$; ns, $P>0.05$. Error bars represent $95 \%$ confidence limits.

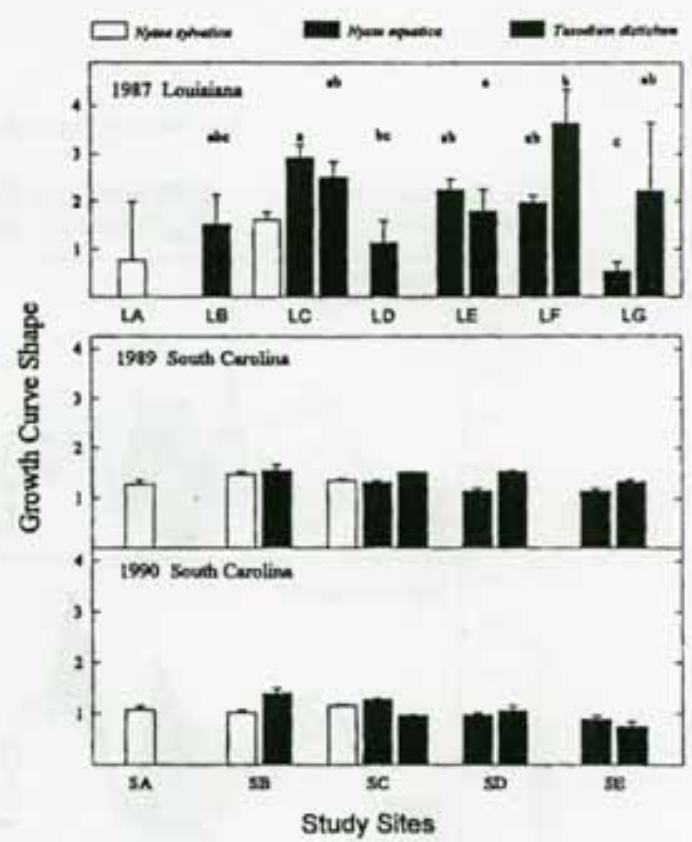

Fig. 8. Diameter growth comparison among study sites, by species. Enor bars represent $95 \%$ confidence limits. Different letters above cach bar represent significant differences among study sites for withia species and within region (year) comparisons only.

Differences in diameter growth among sites were significant for all three species. Growth of $N$. sylvat . ica increased with more frequent and deeper periodic flooding during 1989 in South Carolina, but did not differ among sites in Louisiana (Fig. 8). Significant differences were detected among sites for $N$. aquatica in both regions, but in Louisiana there was no clear relationship between the amount of growth and mean growing season water levels. In South Carolina, trees at the site with periodic deep flooding (SC) grew significantly more than trees at the permanently flooded sites (SD and SE) during both years. A weak trend of greater diameter growth with higher mean growing season water levels was detected for $T$. distichum in Louisiana (Fig. 8). Significant differences in $T$. distichum growth were seen among South Carolina sites in 1990 , but there was no cleaf pattern of growth along the hydrologic gradient. Trees subjected to shallow flooding (periodic or permanent), however, achieved greater growth than trees subjected to deep flooding. 


\subsection{Growth-phase length}

Differences in growth-phase length were significant between regions for all three species. Nyssa sylvatica (1989) and $T$. distichum (both years) grew significantly longer in Louisiana than in South Carolina (Fig. 7). In 1990, N. aquatica trees in South Carolina had a significantly longer growth phase than trees in Louisiana. There were no significant differences in growth-phase length of $N$. sylvatica among sites in either region or of $N$. aquatica in Louisiana (Fig. 9). In South Carolina, N. aquatica trees showed decreasing growth-phase length with permanent and deeper flooding during both years. Taxodium distichum showed no clear pattern of growth-phase length across the range of hydrologic regimes in Louisiana. In South Carolina the growth phase for this species was longest at the site with shallow, permanent flooding (SD) during both years (Fig. 9).

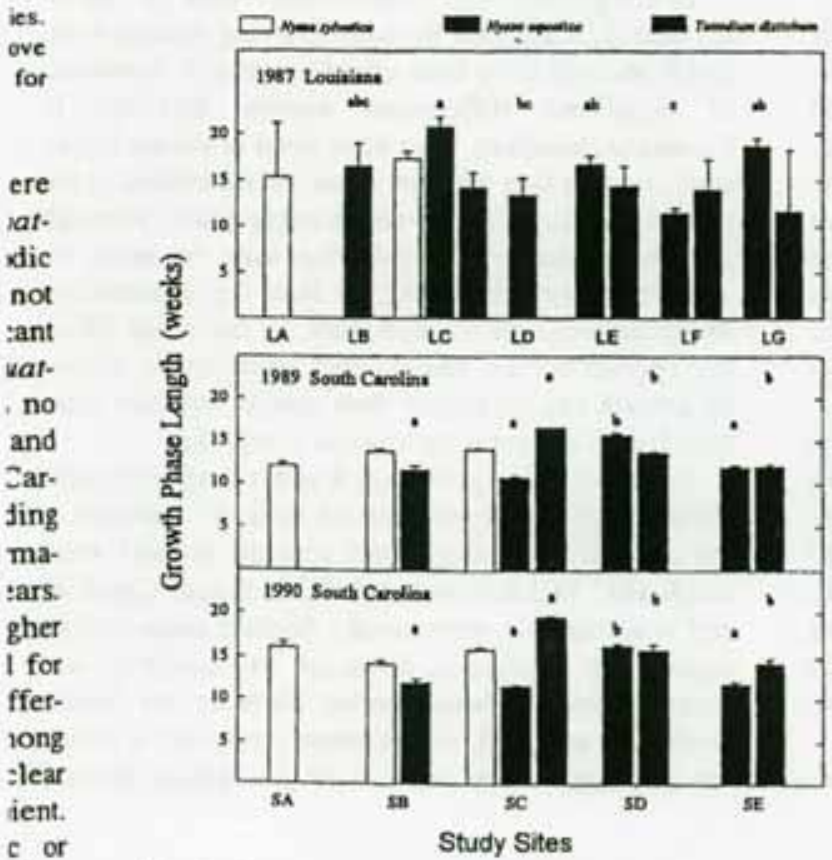

$c$ or

than

Fig. 9. Growth phase length comparison among study sites, by

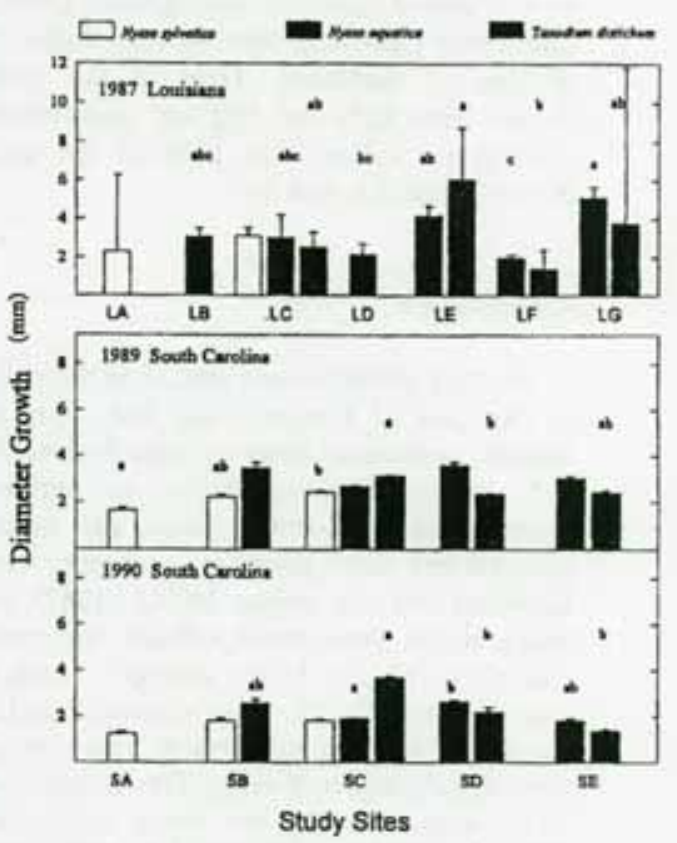

Fig. 10, Growth curve shape $(M)$ comparison among study sites, by species. Symbols as shown in Fig. 8. As $M$ increases, the period of maximum growth occurs later in the growth phase.

\subsection{Growth-curve shape}

Significant differences in growth-curve shape of $N$, aquatica and $T$. distichum were observed between regions both years, but no differences were detected for $N$. sylvatica (Fig. 7). In all significant comparisons, trees in Louisiana had higher curve-shape values, indicating a predominance of growth during the later part of the growth phase. Differences between regions were especially large for $N$. aquatica. In South Carolina, curve-shape values were lower during 1990 than during 1989.

Growth-curve shape for $N$. sylvatica did not differ among sites in either region or year (Fig. 10). Significant differences among sites were observed for $N$. aquatica trees in Louisiana, but the pattern of growth-curve shape values did not correlate with the hydrologic gradient. Taxodium distichum trees subjected to permanent flooding in Louisiana had lower curve-shape values than periodically flooded trees. In species, Symbols as shown in Fig. 8. 
South Carolina there were no significant differences among study sites for any of the species. Significant differences in curve-shape values for $T$. distichum were observed, however, among South Carolina study sites when Louisiana data were excluded (one-way analysis of variance). Trees at the permanently flooded sites (SD and SE) had significantly lower curve-shape values than trees at the periodically flooded sites (SA and SB).

\section{Discussion}

Weather patterns were similar in the two regions, as expected of Coastal Plain sites near the same latitude. Louisiana, however, was generally warmer, had a longer growing season, and received more precipitation. The annual mean and summer high temperatures were near the long-term average for Louisiana (30 year means, NOAA, 1987), but winter temperatures were above average and precipitation was about $10 \mathrm{~cm}$ below average. South Carolina usually has a slightly cooler climate than Louisiana, but during the two summers of study, temperatures were slightly above average. Precipitation was about $10 \mathrm{~cm}$ above the long-term mean in 1989 and $5 \mathrm{~cm}$ below the mean in 1990 (NOAA, 1989, 1990).

Many similarities in the distribution patterns of these species were observed in each region. Nyssa sylvatica was found only in periodically flooded sites, whereas $N$. aquatica was found predominantly in permanently flooded areas of both regions. The zone of overlap in the distribution of the Nyssa species was narrow. Taxodium distichum had the broadest distribution, being present in all study plots except in the periodically flooded sites with the highest elevation and best drainage. All study plots were well within the natural range of each species.

The periodically flooded sites, where $N$. sylvatica occurred, typically had saturated or nearly saturated soils throughout the year. These areas were subjected to high water level variance, with alternately flooded and exposed soil. Bedinger (1971) and Leitman et al. (1982) also reported that $N$. sylvatica was restricted to periodically flooded areas, and Outcalt (1990) reported best growth of this species on sites with permanently saturated soil.

Numerous studies have examined the flood toler- ance of $N$. sylvatica, but most measured the responses of seedlings (Hosner, 1960: Hook et al. 1970: Harms, 1973; Keeley, 1979; Hook et al., 1983). Seedling studies have provided much useful information, but the results cannot necessarily be extrapolated to mature trees (Hall and Smith, 1955; Harms et al., 1980). Keeland (1994) showed significant differences between canopy and subcanopy responses to hydrologic regime. Few studies have examined the growth of mature $N$. sylvatica trees, and comparisons among sites with different hydrologic regimes are rare. Langdon et al. (1978) measured annual growth of nine trees in the Bluebird swamp of South Carolina over a six year period and found mean annual diameter increases of 0.16 to $0.33 \mathrm{~cm}$. Day (1985) reported mean annual growth ranging from $0.02 \mathrm{~cm}$ at a periodically flooded, maple-gum swamp to $0.22 \mathrm{~cm}$ at a rarely flooded, mixed hard. wood site within the Great Dismal swamp of Virginia. These values compared closely with our results of $0.16 \mathrm{~cm}$ (1989) to $0.21 \mathrm{~cm}$ (1990) in South Carolina and of $0.25 \mathrm{~cm}$ in Louisiana (Fig. 8). The extremely low growth of $N$. sylvatica trees in Virginia was similar to the results of Keeland (1994). who reported $0.05 \mathrm{~cm}$ of diameter growth for subcanopy trees of this species in South Carolina.

In the periodically flooded sites where $N$. sylvat. ica occurs, variations in mean growing season water levels seem to have little effect on growth. Detection of significant differences among locations in Louisiana, however, may have been hindered by the small sample size with only two trees included in the pooled site (LA). These results suggest that, although the distribution of $N$. sylvatica may be more re. stricted by hydrologic regime than the distributions of $N$. aquatica or $T$. distichum, in the areas where this species occurs, year-to-year variations in diameter growth can be greater than spatial variation associated with different hydrologic conditions.

Nyssa aquatica grew over a wider range of hydrologic conditions. It co-occurred with $N$. sylvatica at the periodically flooded sites with the highest water levels (LC in Louisiana and SC in South Carolina) and was found in permanently flooded areas in both regions. In Louisiana, however, $N$. aquatica was absent from the least-flooded plots in the Verret basin (LB and LD), where mean water levels during the growing season were at or just below the soil 
surface. Penfound (1952) and Johnson (1990) reported this species to be common in periodically flooded bottomland hardwood forests and in permanently flooded deep-water swamps.

The effects of hydrologic regime on $N$. aquatica survival and growth have been studied extensively. Like $N$, sylvatica, most studies have examined seedling responses (Hosner and Leaf, 1962; Dickson et al., 1965; Kennedy, 1970; Dickson et al., 1972; Harms, 1973; Hook and Brown, 1973; Donovan et al., 1988). Studies of mature-tree responses to hydrologic regime have been more common for $N$. aquatica. Eggler (1955) reported annual diameter growth of $0.20 \mathrm{~cm}$ in southem Louisiana, whereas Conner and Day (1992) observed greater annual diameter increases ranging from $0.36 \mathrm{~cm}$ in an impounded cypress-tupelo swamp to $0.44 \mathrm{~cm}$ in a natural swamp. Day (1985) reported mean annual diameter growth of $0.24 \mathrm{~cm}$ in a cypress swamp and $0.25 \mathrm{~cm}$ in a maple-gum swamp, in the Great Dismal swamp of Virginia. Dicke and Toliver (1990) compared growth of $N$. aquatica in continuously flooded vs. periodically flooded cypress-tupelo swamps in the Verret basin of Louisiana. They reported no significant differences between sites, but the low diameter increases observed $(0.13$ and $0.11 \mathrm{~cm})$ suggest that some factor other than hydrologic regime may have affected growth. These values are, however, comparable with our results from the Verret basin $(0.13$ $\mathrm{cm}$ ).

Thus, our results generally agree with previous findings. Although there were no differences between regions, differences were significant among study sites in each area. In South Carolina, growth was greatest in periodically flooded areas, which agrees with Applequist (1959), who reported best growth of $N$. aquatica when growing season flooding was just short of continuous. The significantly greater growth achieved by this species in 1989 than in 1990 in South Carolina may have been a result of the moisture excess in 1989 compared with the moisture deficit in 1990 (Keeland, 1994). Differences in annual diameter growth among sites in South Carolina seem to have been related to increased growth-phase length (Fig. 7 and Fig. 8), but may also have been influenced by differing stem densities (Table 1), Stem densities were slightly higher at the permanently flooded sites (745 and 785 stems/ha) where growth was less compared with the periodically flooded site $(600$ stems/ha). In Louisiana, we observed mean annual diameter growth ranging from 0.13 to $0.60 \mathrm{~cm}$ among study sites, but the correspondence between growth and hydrologic regime was not clear.

Although the lack of a clear response of $N$. aquatica growth to hydrologic regime in Louisiana may have been a reflection of the small sample size, a confounding factor was defoliation by the tent caterpillar, Malacosoma disstria Hubner, in the Barataria basin (Conner and Day, 1992). This insect has caused reduced growth of $N$. aquatica in Louisiana for several years (J.D. Solomon, personal communication, 1992). Defoliation could explain late growth initiation, low growth, and high growthcurve-shape values observed for this species at site LF in the Barataria basin. A high curve-shape indicates that most growth occurred late in the growth phase. Such curve-shape decretions have been reported for organisms grown under stress conditions, such as waterfowl subjected to contaminated food and tree seedlings grown in heated water (Brisbin and McLeod, 1987).

Taxodium distichum was distributed over the widest range of hydrologic regimes in both regions. Like $N$. aquatica, this species occurred at the periodically flooded sites with the highest water levels (LC in Louisiana and SC in South Carolina). In addition, $T$. distichum occurred at all permanently flooded (backwater) sites in both areas. This species grows in a variety of hydrologic regimes, including permanently flooded to stagnant areas, periodically flooded sites and well-drained upland locations (Mattoon, 1915; Wilhite and Toliver, 1990).

Of the three species included in this analysis, $T$. distichum has been the most intensively studied because of its commercial value. Numerous studies have examined its germination requirements (Mattoon, 1915), seedling response to hydrologic regime (Mattoon, 1916; Demaree, 1932; Dickson et al., 1972: Donovan et al., 1988: Megonigal and Day. 1992), and mature tree growth (Mattoon, 1915; Penfound, 1952; Brown. 1981; Mitsch et al., 1979; Conner and Day, 1992). Extremely variable growth rates have been reported. In Maryland, Mattoon (1915) recorded mean diameter growth of $0.54 \mathrm{~cm}$ per year for second-growth $T$. distichum. This amount luring

e soil 
was nearly double that of virgin trees in Louisiana ( 0.25 to $0.29 \mathrm{~cm}$; Mattoon, 1915). In southern Illinois, Mitsch et al. (1979) reported mean growth of $0.39 \mathrm{~cm}$ per year in a permanently flooded swamp, but annual growth values were variable, ranging from 0.20 to $0.59 \mathrm{~cm}$. Day (1985) reported much lower growth $(0.12 \mathrm{~cm}$ per year) in a Virginia cypress swamp, where flooding extended from January to June. In a study of several cypress swamps in Florida, Mitsch and Ewel (1979) observed annual growth ranging from a low of $0.02 \mathrm{~cm}$ in a ponded cypress dome to $0.33 \mathrm{~cm}$ in a mixed cypresshardwood stand in Florida; no distinction was made between $T$. distichum and $T$. distichum var. nutans (Ait.) Sweet ( $T$. ascendens Brongr.) in that study. Greater growth ( 0.39 to $0.48 \mathrm{~cm}$ per year) was observed in the Barataria basin of southern Louisiana by Conner and Day (1992), whereas Dicke and Toliver (1990) reported annual growth of $0.16 \mathrm{~cm}$ in both permanently and periodically flooded sites in the nearby Verret basin. In our study, diameter growth was similar in each region during the relatively wet years $(0.30 \mathrm{~cm}$ during 1987 in Louisiana and $0.31 \mathrm{~cm}$ during 1989 in South Carolina). Growth was less in 1990 (0.22 cm in South Carolina), possibly a result of the moisture deficit.

A weak pattern of greater $T$. distichum growth with higher mean water levels was observed in Louisiana even though stem densities were higher in the Barataria basin where greatest growth was observed. A similar, weak pattern was observed in South Carolina in 1990; greater growth was associated with shallow permanent flooding. In addition, trees at the permanently flooded sites in both states began growth earlier in the growing season (data not shown) and achieved most growth early in their growth phase (as demonstrated by the low growthcurve-shape values). A significantly longer growthphase length for $T$. distichum in Louisiana may have been related to the longer growing season, but the responses of the two Nyssa species do not support this hypothesis. Nyssa sylvatica had a longer growth phase in Louisiana only when compared with the 1989 South Carolina data, and $N$. aquatica had a longer growth phase in South Carolina. Taxodium distichum may be better able than Nyssa to take advantage of the longer growing season in Louisiana, but the longer growth phase did not result in greater growth when compared with the South Carolina data for 1989. In South Carolina, both annual growth and growth-phase length of $T$. distichum were at a maximum with permanent, shallow flooding, but growth differences among sites were small and the pattern across the hydrologic gradient was not clear. In Louisiana, small growth-curve-shape values were as. sociated with permanent rather than with periodic flooding, and a similar weak pattern was observed in South Carolina. The overall higher growth-curveshape values observed in Louisiana remain unexplained. These results suggest that $T$. distichum can grow well over a wide range of hydrologic conditions.

\section{Conclusions}

The results of this study have shown that few differences were detected in mean annual growth, growth-phase length and growth-curve shape between regional populations of $N$. sylvatica, $N$. aquatica and $T$. distichum. In general, annual variations in these parameters were greater than differences among locations. Differences in hydrologic regime, however, were shown to have significant effects on all parameters for mature trees of all three species. These results suggest that hydrologic regime modifications may have significant impacts on the growth of these species. Increased periodic to permanent shallow flooding would tend to favor Taxodium distichum and Nyssa aquatica while better drainage and more frequent soil exposure would tend to favor Nyssa sylvatica. Although the results of this study shed light on the growth potential of these species in different hydrologic regimes, additional information is needed on how individual trees of these and other species respond to a change in hydrologic regime.

\section{Acknowledgements}

Suggestions for manuscript improvement by James Allen, Mary Davis, Philip Dixon, Kenneth MeLeod, Patrick Megonigal, Robert Wyatt, and Joy Young are gratefully acknowledged. Funding for data collection, analysis, and manuscript preparation was provided by Contract DE-AC09-76SR00-819 between 
vth

ern

In

as-

xdic

1 in

ve-

IeX.

can

ndi-

few

wth.

be-

- N.

aria.

iffer-

Jogic

iicant

three

:gime

n the

errna-

dium

inage

favor

study

ies in

nation

I other

ime.

James

cLeod. ing are collecas proetween the U.S. Department of Energy and the University of Georgia's Savannah River Ecology Laboratory, and by the Louisiana Sea Grant College Program, part of the National Sea Grant Program maintained by NOAA, U.S. Department of Commerce. Permission to use the Louisiana sites was granted by the Miles Timber Co., the White Castle Land, and the Louisiana Wildlife and Fisheries Department. This manuscript is Belle W. Baruch Forest Science Institute Technical Contribution: 94-018.

\section{References}

Applequist, M.B., 1959. Soil-site studies of southern hardwoods. Southern Forest Soils Symposium. L.S.U., Baton Rouge, LA. Pp. 49-72.

Bedinger, M.S, 1971. Forest species as indicators of flooding in the lower White River valley, Arkansas. US Geol. Survey Professional Paper 750-C, pp. 243-253.

Bristin, H., Jr. and MeLood, K.W., 1987. Sigmoid growth and the assessment of hormesis: a case for caution. Health Phys. 52: 553-559.

Brisbin, 1. L. Jt., Collins, C.T., White, G.C. and McCallum, D.A., 1987. A new paradigm for the analysis and interpretation of Erowth data: the shape of things to come. Auk, 104: 553-554,

Brown, S., 1981. A comparison of the structure, primary productivity, and transpintion of cypress ecosystems in Florida. Ecol. Monogr., 51: 403-427.

Conner, W.H. and Day, J.W , Jr., 1976. Productivity and composi. tion of a baldcypress-water tupelo site and a bottomiand hardwood site in a Louisiana swamp. Amer. J. Bot., 63: $1354-1364$.

Conner, W.H., Gosselink, J.G. and Parrondo, R.T., 1981. Comparison of the vegetation of three Louisiana swamp sites with different fooding regimes. Amer. J. Bot., 68: 320-331.

Conner, W.H. and Day, J.W., Jr., 1988. Rising waterlevels in coastal Louisiana: implications for two coastal forested wet. land areas in Louisiana. J. Coastal Res., 4: 589-596.

Conner. W.H. and Day, J.W., Jr., 1992. Diameter growth of Texodium distichum $(\mathrm{L}$.) Rich, and Nyssa equatica $\mathrm{L}$. from 1979-1985 in four Louisiana swamp stands. Amer. Midland Naturalist, 127: 290-299.

Day, F.P. It., 1985. Tree growth rates in the periodically flooded Great Dismal Swamp. Castanea, 50, 89-95.

Day, R.W. and Quinn, G.P.. 1989. Comparisons of treatments after an analysis of variance in ecology. Ecol. Monogr., 59. 433 -463 .

Demaree, D., 1932. Submerging experiments with Tauodium. Ecology, 13: 258-262.

Dicke, S.G. and Toliver, J.R., 1990. Growth and development of baldeypress - water tupelo stands under continuous versus sea. sonal flooding. Forest Ecol. Manage., 33/34: 523-530.

Dickson, R.E., Hosner, J.F. and Hosley. N.W.. 1965. The effects of four water regimes upon the growth of four bottomland tree species. Forest Sci., 11: 299-305.

Dickson, R.E., Broyer, T.C. and Johnson, C.M., 1972. Nutrient uptake by tupelo gum and baldcypress from saturated or unsaturated soil. Plant Soil, 37: 297-308.

Donovan, L.A., McLeod, K.W., Sherrod, K.C., Ir., and Stumpff. N.J., 1988. Response of woody swamp seedlings to flooding and increased water temperahures. I. Growth, biomass, and survivorship. Amer. J. Bot., 75: 1181-1190.

Eggler, W.A., 1955. Radial growth in nine species of trees in southem Louisiana. Ecology, 36: 130-136.

Fritts, H.C., 1956. Relations of radial growth of beech (Fagis grandifolie Ehrh.) to some environmental factors in a central Ohio forest during 1954-1955. Ph.D. Thesis, Ohio State University, Columbus, $\mathrm{OH}, 129 \mathrm{pp}$.

Gleason, H.A.4 1926. The individualistic concept of the plant association. Bull, Torrey Bot, Club, 53: 7-26.

Hall, T.F. and Smith, G.E., 1955. Effects of flooding on woody plants, west sandy dewatering project, Kentucky reservoir. J. Forest., 54: 281-285.

Harms, W.R., 1973. Some effects of soil type and water regime on growth of tupelo seedlings. Ecology, 54: 188-193.

Harms, W.R., Schreuder, H.T., Hook. D.D., Brown, C.L. and Shropshire, F.W., 1980. The effects of flooding on the swamp forest in Lake Ocklawaha, Florida. Ecology, 61: 1412-1421.

Hook, D.D. and Brown, C.L., 1973. Root adaptations and relative flood tolerance of five hardwood species. Forest Sci. 19. 225-229.

Hook, D.D., Langdon, O.G. Stubbs, J. and Brown, C.L. 1970 Effect of water regimes on the survival, growh, and morphology of tupelo scedlings. Forest Sci, 16: 304-311.

Hook, D.D., Debell, D.S., McKee, W.H., Jt. and Askew, J.L. 1983. Responses of loblolly pine (mesophyte) and swamp tupelo (hydrophyte) seedlings to soil flooding and phosphorus. Plast Soil, 71: 387-394.

Hosner, J.F., 1960. Relative tolerance to complete inundation of fourteen bottomland tree species. Forest Sci., 6: 246-251.

Hosner, J.F. and Leaf, A.L. 1962. The effect of soil saturation upon the dry weight, ash content, and nutrient absorption of various bottomland tree seedlings. Soil Sci. Soc. Proc., 26: $401-404$.

Hughes, F.M.R., 1990. The influence of flooding regimes on forest distribution and composition in the Tana River floodplain, Kenya. J. Appl. Ecol., 27: 475-491.

Johnson, R.L. 1990, Nyssa aguarica L., water tupelo. In: R.M Burns and B.H. Honkala (technical coordinators), Silvies of North America: 1. Conifers. Agriculture Handbook 654, US Department of Agriculture, Forest Service, Washington, DC, Vol, 1, pp, 474-478.

Keeland, B.D. 1994. The effects of variations in hydrologic regime on diameter growth in Nyssa aquatica, Nyssa syluatica var, biffore, and Taxodiwm distichum. Ph.D. Dissertation. University of Georgia, Athens, GA, 179 pp.

Keeley, J.E., 1979. Population differentiation along a flood frequency gradient physiological adaptations to flooding in Nysua syluatica. Ecol. Monogr. 49: 89-108. 
Kennedy, H.E., Jr., 1970. Growth of newly planted water tupelo seedlings after flooding and siltation. Forest Sci., 16: 250-256.

Kozlowski, T.T., 1984, Plant responses to flooding of soit. BioScience, 34: 162-167.

Langdon, O.G., DeBell, D.S, and Hook, D.D., 1978. Diameter growth of swamp tupelo: seasonal patiern and relation to water table level. Fifth North American Forest Biology Workshop Proceedings, Univ, Fla., Gainesville, pp. 326-333.

Lange, O.L., Losch, R.s Schulze, E.-D. and Kappen, L., 1971. Responses of stomata to changes in humidity. Planta, 100: 76-86.

Leitman, H.M., Sohm, J.E. and Franklin, M.A., 1982. Wetland hydrology and tree distribution of the Apalachicola river flood plain, Forida. U.S.G.S. Open-File Report $82-251.92$ pP.

Mattoon, W.R. 1915. The southern cypress. USDA Agricultural Bulletin Number 272, 74 pp.

Mattoon, W.R., 1916. Water requitements and growth of young cypress. Soc, Am. For, Proc., II: 192-197.

MeCallum, D.A, and Dixon, P.M., 1990. Reducing bias in esti. mates of the Richards growth function shape parameter. Growth Develop. Aging. 54: 135-141.

Megonigal, J.P. and Day, F.P.. 1988. Organic matter dynamics in four seasonally flooded forest communities of the Great Dis. mal Swamp. Amet. J. Bot, 75: 1334-1343.

Megonigal, J.P. and Day. F.P.. 1992. Effects of flooding on root and shoot production of baldeypress in large experimental enclosures. Ecology, 73: 1182-1193.

Mitsch, W.J., Dorge, C.L. and Wiemhoff, J.R., 1979. Ecosystem dynamics and a phosphorus budget of an alluvial cypress swamp in southern Illinois. Ecology, 60, 1116-1124.

Mitsch, W.J. and Gosselink, J.G., 1993. Wetlands, 2nd edn. Van Nostrand Reinhold, New York, NY, USA, 537 Pp.

Mitsch, W.J. and Ewel, K.C., 1979. Comparative biomass and growth of cypress in Florida wetlands. Amer. Midland Naturalist, 101: $417-426$

Monk, C.D. and Brown, T.W. 1965. Ecological consideration of cypress heads in northcentral Florida. Amer. Midland Naturalist, $74: 126-140$.

Muller, R.A., 1975. Freshwater potential in the Louisiana coastal marshes and estuaries, In: H.J. Walker (Editor), Coastal Re. sources, GeoScience and Man, Vol. XII. School of GeoScience, Publication Section, LSU, Baton Rouge, LA, pp. 1-7.

NOAA, 1987. Climatological data annual summary, Louisiana, 92(13).

NOAA, 1989. Climatological data annual summary, Sooth Carolina, $92(13)$.

NOAA, 1990. Climatological data annual summary. South Car olina, $93(13)$.

Outcalt, K.W. 1990. Nyssa sylvarice var. biflare (Walt.) Sarg.swamp tupelo. In: R.M. Bums and B.H. Honkala (technical coordinators), Silvics of North America: 2. Hardwoods. Agri. culture Handbook 654, US Department of Agriculture, Forest Service, Washington, DC. Vol 2, pp. 485-489.
Paratley, R.D. and Fahey. T.J. 1986. Vezetation environment relations in a conifer swamp in central New York Bull. Torrey Bot. Club, 113: 357-371.

Parker, J.. 1950. The effects of nooding on the transpiration and survival of some southeastern forest tree species. Plant Physiol., 25: 453-460.

Pearlstine, L., 1985. FORFLO: a bottomland forest floodplain model - user's manual and programming notes, versions I.OA and 1.0B for Data General Computers. US Fish Wildl. Serv, NCET Open File Rep, 85-3, 92 pp.

Penfound, W.T., 1952. Southern Swamps and Marshes. Bot. Rev., 18: $413-446$.

Phipps, R.L., 1979. Simulation of wetland forest vegetation dy. namics. Ecol. Model., 7: 257-288.

Phipps, R.L. and Applegate, L.H., 1983. Simulation of management alternatives in wetland forests. In: S.E. Jorgensen and WJ. Mitsch (Editors). Application of Ecological Modeling in Environmental Management, Part B. Elsevier, Amsterdam, pp. $311-339$.

Rogers, V,A., 1990. Soll Survey of Savannah River Plant Area, parts of Aiken, Barnwell and Allendale counties, South Carolina. USDA, Soil Conservation Service, Washington, DC.

SAS Institute Inc., 1988. SAS/STAT User's Guide, Release 6.03 Edition. SAS Institute, Cary, NC, 1028 pp.

Schlesinger, W.H. 1978. Community stnucture, dynamics and nutrient cycling in the Okefenokee cypress swamp-forest. Ecol. Monogr., 48: 43-65.

Snedecor, G.W. and Cochran, W.G. 1980. Statistical Methods. Jowa State University Press, Ames, IA, 593 pp.

Thomthwaite, C.W. and Mather, J.R., 1955. The water balance. Laboratory of Climatology. Publ. 8, Centerton, NJ.

Turner, N.C., Schulze, E.-D, and Gollan, T., 1984. The responses of stomata and leaf gas exchange to vapour pressure deficits and soil water content. I. Species comparisons at high soil water contents. Oecologia, 63: 338-342.

Weller. M.W.. 1989. Plant and water-level dynamics in an east Texas shrub/hardwood bottomland wetland. Wetlands, 9: 7388.

Wharton, C.H., Kitchens, W.M., Pendleton, E.C. and Sipe, T.W.. 1982. The ecology of bottomland hardwood swamps of the southeast: a community profile, US Fish and Wildlife Service, Biological Services Program FWS/OBS-81/37, 133 pp.

White, D.A. 1983. Plant communities of the lower Pearl river basin, Louisiana. Amer. Midland Naturalist, 110. 381-396.

White, G.C. and Ratti, J.T., 1977. Estimation and testing of parameters in Richards growth model for westem grebes. Growth, 41: 315-323.

Whittaker, R.H., 1956. Vegetation of the Great Smoky mountains. Ecol. Monogr., 26: 1-80.

Wilhite, L.P. and Toliver, J.R., 1990. Tarodium disticham (L.) Rich., baldcypress. In: R.M. Burns and B.H. Honkala (technical coordinators). Silvies of North America: 1. Conifen. Agriculture Handbook 654. US Department of Agriculture. Forest Service, Washington, DC, pp. 563-572. 